\title{
The Models of Distance Forms of LEARNING IN NATIONAL ACADEMY OF STATISTICS, ACCOUNTING AND AUDIT
}

UDC: 004:37

JEL Classification: Z0

\author{
L. V. DERYHLAZOV, \\ PhD (Phys. \& Math.), Professor, \\ Head of the Correspondence and Distance Learning Department, \\ National Academy of Statistics, Accounting and Audit \\ V.M KUKHARENKO, \\ PhD (Engineering), Professor, \\ Scientific Supervisor of Problem Laboratory for Distance Learning \\ National Technical University "Kharkiv Polytechnic Institute" \\ L. P. PERKHUN, \\ PhD (Pedagogical Sciences), Associate Professor, \\ Head of the Distance Learning Unit, \\ National Academy of Statistics, Accounting and Audit \\ N. M TOVMACHENKO, \\ PhD (Engineering), Associate Professor, \\ Department of Statistics, \\ National Academy of Statistics, Accounting and Audit
}

\section{The Models of Distance Forms of Learning in National Academy of Statistics, Accounting and Audit}

Finding solutions to the problems faced by the Ukrainian education system require an adequate organizing structure for education system, enabling for transition to the principle of life-long education. The best option for this is the distance learning systems (DLS), which are considered by leading Ukrainian universities as high-performance information technologies in modern education, envisaged by the National Informatization Program, with the goals of reforming higher education in Ukraine in the context of joining the European educational area. The experience of implementing DLS "Prometheus" and Moodle and the main directions of distance learning development at the National Academy of Statistics, Accounting and Audit (NASAA) are analyzed and summed up. The emphasis is made on the need to improve the skills of teachers with use of open distance courses and gradual preparation of students for the learning process in the new conditions. The structure of distance courses for different forms of education (full-time, part-time, and blended) is built. The forms of learning (face-toface, the driver complementary, rotation model; flex model, etc.) are analyzed. The dynamic version of implementing blended learning models in NASAA using DLS "Prometheus" and Moodle is presented. It is concluded that the experience of NASAA shows that the blended form of distance learning based on Moodle platform is the most adequate to the requirements of Ukraine's development within the framework of European education.

Keywords:, distance learning, distance learning system, blended learning, life-long education, information technologies, distance learning course, "Prometheus", Moodle.

The purpose of this study is to analyze and generalize the experience of organizing and developing the distance learning system (DLS) in the National Academy of Statistics, Accounting and Audit of the State Statistics Service of Ukraine (NASAA), introduced in Ukraine as part of the National Informatization Program [1].

Results. The analysis shows that the blended form of training is the most suitable in the NASAA conditions, which is a combination of on-line forms with traditional forms of in-patient and correspondence training, using learning management system (LMS ) Moodle.

Introduction. The most important issue of reforming higher education in Ukraine is joining the European Education Area. Special attention is paid to the lifelong learning program in modern Europe - the Lifelong Learning Program, which is the successor to the ICT / Open \& Distance Learning Program [2].

The National Academy of Statistics, Accounting and Audit of the State Statistics Service of Ukraine is the basic organization of the industry, which trains specialists in applied statistics for the national statistical service.

(C) L. V. Deryhlazov, V. M. Kukharenko, L. P. Perkhun, N. M. Tovmachenko, 2017 
The statistical service of Ukraine is based on regional statistical organizations, it has hierarchical structure headed by State Statistics Service of Ukraine (http://ukrstat.gov.ua/). The problem of improving the quality of training and professional retraining for the official statistics system in Ukraine and enhancing their skills through creating and operating relevant information technologies and DLS is considered now as an extremely important component of the overall objective of improving the quality and efficiency of the higher and secondary specialized education in Ukraine.

However, there is a shortage of professionals for work in the central and regional official statistical offices. The objective of distance learning (DL) is to fill this gap and further develop professional training for official statistics, which is highlighted in the Strategy of Official Statistics Development of 2012, in the priorities of the Ukraine - EU Action Plan within the framework of the statistical program $[3 ; 4]$.

The Resolution of Cabinet of Ministers of Ukraine from March 20, 2013 No. 145-p "On Approval of the Strategy for the Development of State Statistics for the Period till 2017" (http://zakon3.rada.gov.ua/laws/show/145-2013-p/page) provides for the establishment of a distance learning center for statistics officers.

DL technology in NASAA was initially introduced through DLS "PROMETHEUS" (www.prometeus.ru), used in professional training in the field of "applied statistics", "accounting and audit" and others (http: //nasoa.edu.ua). DL technologies can be used not only in distance education (DE), but also in other forms of education: full-time, part-time, in separate disciplines or in blocks of disciplines intended to enhance the education level or qualifications of individuals and/or groups of listeners.

Implementation and experience of using DLS "PROMETHEUS" 4.2. At the phase of application of DLS "PROMETHEUS", the organizational and pedagogical tendency in DL development in NASAA was associated with adaptation of work programs, syllabi of educational disciplines, quality control systems of DL, already existing and adjusted to the current requirements of curricula using the traditional ADDIE technology [5] (Fig. 1).

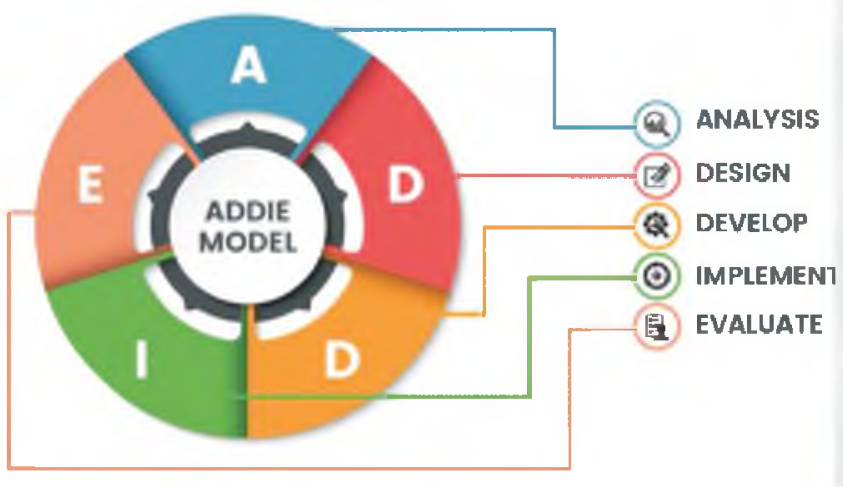

Fig. 1. ADDIE design technology

DL technologies were introduced in the academic process of NASAA in 2007. Since then more than 200 courses have been developed and used successfully in training on specialties "Accounting, Audit and Taxation", "Applied Statistics and Analytics", "Finance, Banking and Insurance" at the educational levels of Bachelor and Master.

From March 2, 2007 till the end of December 2015, DLS "PROMETHEUS" was used in NASAA.

DLS "PROMETHEUS" was developed taking into account the world-wide experience of the organization and development of the university system of distance learning and participation in the European Conference on DL in London.

Among the EU countries, the oldest system of DE is British one. The Open University of the Great Britain (http://www.open.ac.uk) was founded in 1969 as an independent education institution to provide a "second" chance to finish or continue education for adult people who work. At the University of London, a special project was created - London University 


\section{The Models of Distance Forms of LEARNING in National A CADEMY OF Statistics, ACCoUnting AND AUdit}

"External Program" (http://www.londoninternational.ac.uk). This is a separate division dealing with distance programs.

The Open University of Great Britain has established itself as the world leader in DE. According to the model of the Open University of Great Britain, education institutions of the same type were created in the USA, Canada, Austria, Netherlands, France, Germany, Russia, Spain, Pakistan, Turkey, India, Israel, etc.

Ukraine, along with 11 countries of the Commonwealth of Independent States (CIS), is a participant of the project "Informatization of Education and Distance Learning" (http:// cis.rudn.ru).

The State Academy of Statistics, Accounting and Audit (now NASAA) acquired a paid version of DLS "Prometheus" in 2007 and received the license. DLS "Prometheus" has a modular architecture allowing for expanding, upgrading and scaling the system as needed. The distance course and related objects of DLS "Prometheus" have the following components: a calendar plan, educational materials, tests, tasks, groups of listeners, information exchange (forums, conferences).

The level of intelligence of statistical works and statistical analysis of data, conducted in official statistics, has increased in recent years. This requires profound studies and use of modern statistical packages, development of educational technology for the formation of transcendental mental activity. NASAA has an academic license to use statistic package the Predictive Analytics SoftWare (PASW). PASW is a comprehensive software for predictive analysis at all the phases of the analytical process, which includes data collection, forecasting and evaluation of alternative options, rapid and reliable application of results in support processes and decision making [6]. The experience of providing education services, practical research of domestic higher education institutions, including the National Academy of Public Administration under the President of Ukraine, practices of DE forms implementation and own experience of NASAA, presented at international scientific and practical conferences, were used [7-10].

In 2012, the agreement on DE was signed between NASAA and Khmelnitsky National University (KhNU). Within its framework 98 distance courses for economic specialties were developed. Aspects of DE introduction in Ukraine, history, the current state and trends in DL development in global, national, NASAA and KhNU level are discussed in [11]. Conceptual models for implementation of DL in NASAA and KhNU were used for blended learning, that is, they combine traditional daytime, correspondence learning with DL, and laid the foundation for lifelong learning for on-the-job training.

The analysis of international experience in DL technology in higher education institutions was carried out in DLS of the Prometheus system 4.2 and used for the educational process of NASAA in distance courses in the education process for professional training in the discipline 0305 "Economics and Business", fields of "Banking", "Economic Cybernetics", "Management", "Accounting and Audit", "Applied Statistics", "Finance and Credit" $[2 ; 12-13]$.

Apart from the author of the distance course, a teacher and a programmer, an experienced methodologist, designer and other specialists take part in distance courses on the basis of DLS "Prometheus" 4.2.

From 2007 till 2009, an Internet-based form of DL - the model "Face-to-face Driver or Complementary classroom instruction" - was used in NASAA at the first phase of DL implementation with use of this DLS platform [14].

Face-to-Face Driver ("Driver - full-time education") is a model in which the teacher himself provides the core curriculum, by embedding online learning as an auxiliary one if needed. This model often includes class and laboratory work on computers.

The teacher's role is central in this model, with function of on-line learning being auxiliary, face-to-face training taking place in a computer class.

On-line (synchronous, scheduled) lectures, seminars may have the following operative scheme: before the appointed time, listeners (students) come to the web-site to register, after that the classes begin. The lesson is conducted by a teacher (tutor) answering the questions of "listeners" online. The percentage of distance learning is within 20.

This is the most common "way" to create a DLS, which can now be found on the web: translation of teaching materials into an HTML form and their display on web-sites of 
educational institutions. Of course, this is an important phase, but the design of an educational material in web form and lack of access to it via Internet does not bring any innovation in the learning process itself. Translating a textbook (manual) in the HTML-structure and allowing to read it does not mean creating a DL course on the subject.

From 2010 till 2012, NASAA used a DL form via Internet - "Rotation model", which, along with traditional training, used on-line training.

"Rotation Model" is a model with rotation of the traditional timeline of classroom education and individual online learning in the personal mode (for example, via the Internet under the reference plan, compiled by a blended program teacher, on a special web-site).

Rotation model of training is implemented in one discipline/course and provides alternating student and student (or student group) classroom teaching and indirect interaction of participants in the learning process using information and communication technologies. The order of changing the forms of study can be fixed (on schedule) or flexible at the teacher's discretion, and the percentage of DL is 30 .

The next step in using DLS "Prometheus" 4.2, implemented from 2013 till 2014, was "Flex Model" with the mainstream of on-line training and the supportive role of the tutor as needed.

"Flex Model" is a model in which the online platform is mostly used, with teacher supporting students as needed or occasionally, from time to time, working with small groups of students or one student.

In a flexible model, a course or subject in which the online component is the basis for student learning, even if certain activities are offline. Students work on an individual and flexible schedule including various forms of tuition. A teacher is accessible for any counseling. and students learn, mostly in the classroom, and perform individual homework. The teacher is ready to provide support, if necessary, through actions such as work in small groups of learning, group projects, as well as individual counseling. There are examples of implemented flexible models, in which a tutor gives more or less support. This ratio needs to be adjusted for a specific higher education institution and the goal of blended learning, with approximately 40-percent share of DL.

As most of the domestic higher education institutions use the Moodle open educational platform for organization and technical support of DL, NASAA has also benefited from this on-the-spot learning platform and started to use the free DLS Moodle version 2.9 [15].

Implementation and experience of using DLS Moodle version 2.9. Learning is not only reading of educational materials, but active reflection and application of the knowledge in practice.

"Activity" of comprehension is often expressed in students asking questions to a teacher, and such an opportunity should be given by DLS. In addition, the material itself must be constructed in a way "provoking" the question. Yet, a teacher must be on "the other end of the line", to answer the question in real time for the synchronous course, or at least very quickly for the asynchronous one.

To transfer the distance course (DC) developed in the DLS "Prometheus" 4.2 , in the DLS Moodle 2.9, the SCORM package for the DC was created according to the rules of the courses of the DLS "Prometheus" 4.2 .

At this phase, the model Online Lab ("Online Laboratory") prevailed. In this model, the online platform is used to transfer the entire course to face-to-face training. Such training is supervised by a teacher, and the share of distance learning reaches $55 \%$. Such a program can be combined with the classic one within the normal schedule.

Moodle system is currently integrated into NASAA information and education environment, including fully synchronized bases of teachers and students, each with a personal profile on the web-site; from the personal cabinet scientific, educational, methodological, regulatory and information resources of NASAA (electronic library, repository, electronic journal, database of teaching materials, Moodle system, etc.) can be accessed.

To ensure DL quality at NASAA, a package of regulatory documents on DC quality and quantity was developed. Additionally, there are regular courses of teacher training in DL technology.

Moodle has sophisticated communications tools, including messaging system and calendar. In addition, teachers use other means of communication in parallel: social networks, Skype, e-mail, etc. 
All DC of NASAA in the Moodle system are stored in the following categories: "Bachelor's Degree", "Bachelor's Degree Remote", "Trainings", "Master", "Second Higher Education", "Academic Difference", "Success", "Instructions", "Advanced Training".

DC structure for DL students is presented in Fig. 2.

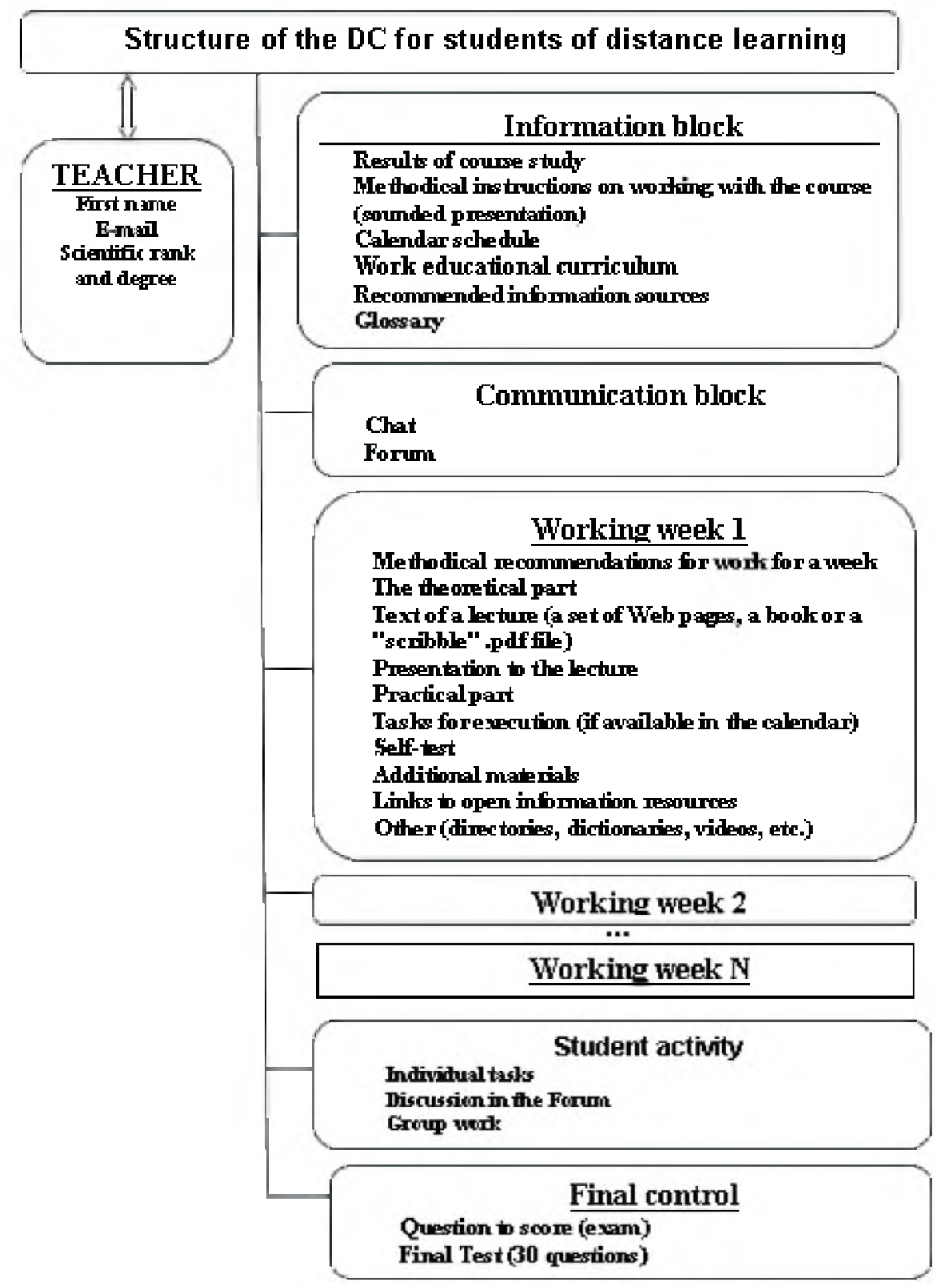

Fig. 2. Structure of Distance Course for Students of Distance Learning

Training courses are structured in form of a modular system and include the following elements: theoretical material (lecture texts), practical tasks (problems, questions, tests for self-examination), and tasks for knowledge checking (tests, virtual laboratory and coursework, etc.), video clips (video lectures); electronic resources (e-mail, skype, chats, etc.).

It should be emphasized that the main difference between an online training course and a presentation or a web-site are not only information access, but the interactive character of knowledge control and accumulation of information about the process of students. 
Accumulation of information about the learning process and the finished courses appears to be especially important in case of the corporate-based DLS, as it allows staff of personnel department and managers to have very important information about training activities of staff (tutors) in time of their training.

In 2016, the Self-Blend Model was used in NASAA on the platform of DLS Moodle 2.9.

The model "Do it yourself" (Self-Blend or A La Carte) allows students to choose additional courses for basic education. Various educational institutions can serve as providers of educational services. This model of blended learning can be effective given high motivation of students.

It is up to a student to decide which of the DC he needs to supplement with remote online activities, and the share of on-line training is $70 \%$.

In order to adapt the NASOA teachers to working conditions in the DLS Moodle, the NASAA administration organized training of teachers in the framework of the open-end distance course "Technologies for the development of the distance course TRDK-2016" (KhNADU, Prof. V. M. Kukharenko). The program of the open DC TRDK-2016 consisted of the following modules: designing DC contents, informational materials, testing, evaluation and communication. The theoretic basis for learning was the so-called ADDIE approach [16] and the Online Driver Model [19], in which the percentage of DL is not less than $85 \%$.

The following scheme for organizing online DL course was used:

- tasks for students, with the performance checked and evaluated;

- dialogue with a listener: "questions and answers" function.

Teachers participated as specialists in the subject area - carriers of knowledge on the training course translated into online form. During the training the teachers developed DL courses on applied statistics, informatics, accounting, audit, management, insurance, marketing, and the Ukrainian language (by professional orientation).

In the course on technology for DL development 16 persons were registered, of which $43.75 \%$ ( 7 persons) had experience of distance courses development, and $56.25 \%$ (9 persons) were with experience of tutorial work. All the registered students participated in the training, with $87.5 \%$ (14 persons) working actively, but everyone could finish the program of the course.

NASAA prepared 16 tutors of DL, who, having finished successfully the program of open DC, received certificates and diplomas.

A barrier to introduction of distance technology in the education and spread of DL is inertness originating from the inward conservatism of teaching staff that does not have appropriate practical experiences. Therefore, a training webinar in NASAA (for its teachers) was held later using the Open Meetings platform. This webinar was conducted before the beginning of the semester for full-time teachers who would develop the content of the course, and the teachers who would hold the classes. Moreover, teachers are familiar with what is expected of them, and with information about the development of the system. Also, at this meeting all the necessary teaching subjects were presented, taking into account the teachers' proposals on the curriculum structure.

Since 2016, distance education at NASAA has been realized on the basis of the platform DLS Moodle 2.9, through the distance education unit at the correspondence and distance education department of NASAA. The unit operates under the general supervision of the head of the correspondence and distant learning department. The unit head is responsible for methodological support of control over execution of training programs and plans, programs and plans of research; he organizes and controls the performance of contractual obligations. The distance education unit is staffed with technical administrators - software engineers, web designers, tutors developing distance course, methodologists who communicate with students and form their individual trajectory of training.

Using DLS Moodle 2.9 in NASAA in 2016-2017 at Bachelor's and Master's level, DL is based on a combination of full-time and distance form, in two versions: the first one involves presence of students in a classroom at the beginning of a semester (to be introduced to organization of training and structure of courses) and at the end of a semester (for exams), and DL during a semester; the second one involves DL during a semester and student attendance only at exams. 
The evaluation is based on the results of tests and tasks in the middle of the semester, homework, attending virtual classes, following course contents and other types of work, as well as the results of the sub-check-up work and the final test on the schedule in the day of exams.

Having finished DL, a NASAA student receives an official Bachelor's or Master's Degree diploma, which is similar to ones received by students of other forms of training.

Consequently, blended learning [17-19]:

- expands education opportunities of students through accessibility and flexibility, taking into account their individual education needs, as well as the pace and scopes of their learning;

- stimulates formation of the student's subject position: the increased motivation, independence, social activity, reflection and self-awareness and, as a result, the increased efficiency of the educational process as a whole;

- transforms the teachers' style: translation of knowledge abandoned and interinteractive interaction with a student adopted, helping to construct self-learning;

- personalizes the educational process: a student independently determines his inschool goals, ways of achieving them, taking into account his education needs, interests and abilities, the teacher (tutor) is also an assistant of a student.

Figure 3 presents a dynamic version of implementation of blended learning models in NASAA using DLS "Prometheus" 4.2 and DLS Moodle (versions 2.9 and 3.2), and the corresponding percentage of DL.

Conclusion. Analysis of the experience of implementation and use of the DLS "Prometheus" 4.2 and Moodle at NASAA shows that the blended form of DL based on Moodle platform is the most appropriate for the development of Ukraine within the framework of European education.

NASAA experience demonstrates that mixed learning requires an in-service teacher's training with open distance courses and in-patient training for a student in a new learning environment.

The analysis of implementation of DLS Moodle in NASAA shows that currently the NASAA professors qualified in the subject area should be given the opportunity to upgrade their qualifications in DC "Curator of Content". 


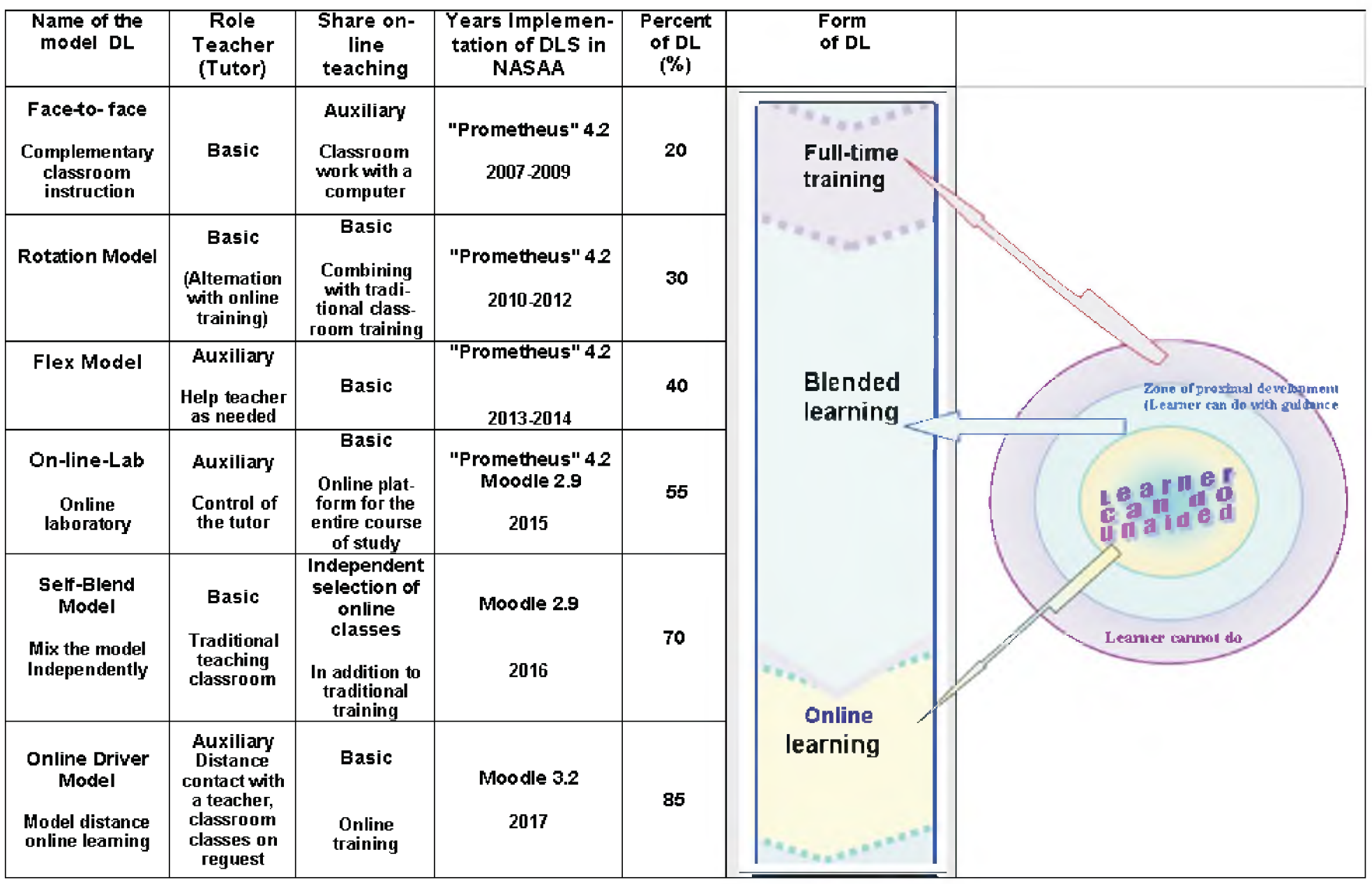

Fig. 3. Distance learning models of NASAA using DLS "Prometheus" and Moodle 


\section{References}

1. Zakon Ukrainy "Pro natsionalnu prohramu informatizatsii" (data nabuttya chynnosti 12 bereznya 1998 r.) [The Law of Ukraine "National program of informatization", enforced March 12, 1998]. Retrieved from http://zakon4.rada.gov.ua/laws/anot/74/98- \%D0 \%B2 $\%$ D1 \%80 [in Ukrainian].

2. Krasin, M. A. \& Karpov, V. I. \& Tovmachenko N. M. (2013). Perspektyvnyi pidkhid do orhanizatsii navchalnoho protsesu. Dosvid rozvytku vishchoi osvity u Polshchi [The advanced approach to organization of the learning process. Experiences of higher education in Poland]. Naukovyi visnyk Natsionalnoi akademii statystyky, obliku ta audytu

- Scientific bulletin of the National Academy of Statistics, Accounting and Audit, 4, 109-118 [in Ukrainian].

3. Osaulenko, O. G. \& Pylypenko, 1. 1. \& Karchev, Y. Y. (2009). Problems of Raising the Level of Statistical Literacy in Ukraine. State Statistics in Ukraine: Current state of affairs, problems, perspectives, 3-9.

4. Osaulenko, O. G. \& Pylypenko, 1. 1. \& Karchev, Y. Y. (2009). State Statistics Development Strategy 2012. Plan and Eurostat's Community Statistical Programme 2008 to 2012.

5. Kukharenko, V. M. \& Rybalko, O. V. \& Syrotenko, N. G. (2002). Dystanziyne navchannya: umovy zastosuvannya [Distance learning: conditions for applications]. Kharkiv: NTU "KHPI", "Torg". 320 p. [in Ukrainian].

6. SPSS European Directions Conference 2009, Prague, Czech Republic, 11-14 May, 2009. Tovmachenko, N. An Application of SPSS in Education and its Using for Sampling Research of Ukraine (Poster report). Retrieved from http://www.spss.com/spssdirections/emea.

7. Tovmachenko, Nina \& Zhuravlov, Andriy (2010). The Application of PASW Statistics in statistical Education and its Usage for Distance Learning in the Ukraine. 8th International Conference on Teaching Statistics (ICOTS8), Ljubljana, Slovenia. July, 2010. Retrieved from https://iase-web.org/documents/papers/icots8/ICOTS8_P13_ TOVMACHENKO.pdf

8. Tovmachenko, N. M. \& Karpov, V. I. \& Derigalov, L. V., Parfentseva, N. O. \& Zhuravlev, A. V. (2011). Perspektyvy ta rozvytok distantsiynoho navchannya v Natsionalniy akademii statystyky, obliku ta audytu [Prospects and development of distance learning in the National Academy of Statistics, Accounting and Audit]. Proceedings from: Technolohii distantsiynoi (elektronnoi) osvity $v$ suchasniy derzhovniy kadroviy politytsi: persha naukovo-praktychna konferentsia-vystava za mizhnarodnoi uchasti-Technologies of distance (online) education in the current policy of human resources: the first scientific and practical conference-exhibition with international participation. Kyiv, 26 May 2011. (pp. 210-214). Kyiv: National Academy of Public Administration under the President of Ukraine [in Ukrainian].

9. Tovmachenko, N. M. \& Karpov, V. I. \& Deryglazov, L. V. \& Parfentseva, N. O. (2011). Kontseptsii pobudovy i osnovni skladovi informatsiynoi systemy dystantsiynogo navchannya $v$ Natsionalniy akademii statystyky, obliku ta audytu [Conceptualization and key components of the information system for distance learning in the National Academy of Statistics, Accounting and Audit]. Proceedings of the international scientific and practical conference: Dystantsiyna osvita v Ukraini: Informatsiyne osvitne seredovyshche u systemi dystantsiynoho navchannya $v$ zakladakh osvity: innovatsiyni ta psykholoho-pedahohichni aspekty - Distance education in Ukraine: Information and education environment in the distance learning system of education institutions: innovation, psychological pedagogical aspects. (pp. 375-380). Kharkiv [in Ukrainian].

10. Pylypenko, Ivan \& Karpov, Volodymyr \& Karchev, Yakiv \& Tovmachenko, Nina (2010). Using distance learning platform for the application of predictive analytic software of statistics in statistical education in Ukraine. International Conference on Modern Stochastic Theory and Applications II, September 7-11, 2010, Kyiv, Ukraine.

11. Karpov, V. I. \& Mazur, M. P. \& Tovmachenko, N. M. (2014). Aspekty vprovadzhennya dystantsiynoi osvity v Ukraini [Distance education in Ukraine: aspects of introduction]. Naukovyi visnyk Natsionalnoi akademii statystyky, obliku ta audytu-Scientific bulletin of the National Academy of Statistics, Accounting and Audit, 4, 87-95 [in Ukrainian]. 
12. Garkusha, V. Z. \& Tovmachenko, N. M. \& Kurbatov, O. O. (2007). Application of learning management system (LMS) "Prometey" in the State Academy of Statistics, Accounting and Audit (SASAA) of the State Statistics Committee of Ukraine. Prykladna statystyka: problemy teorii ta praktyky - Applied statistics: problems of theory and practice. (pp. 18-27). Kyiv: "Informaz.-analit. ahenstvo".

13. Garkusha, V. \& Tovmachenko, N. \& Kurbatov, O. (2009). About application of information technologies in the State Academy of Statistics, Accounting and Audit of the State Committee of Statistics of Ukraine with use of the system of distance learning "PROMETHEUS". Naukovyi visnyk Derzhavnoi akademii statystyky, obliku ta andytuScientific bulletin of the State Academy of Statistics. Accounting and Audit, 1, 102-108.

14. 14. Powell A., Watson J., Staley P. et al. (2015). Blending Learning: The Evolution of Online and Face-to-Face Education from 2008-2015. Promising practices in blended and online learning. July, 2015 p. 20. Retrieved from http://www.inacol.org/wpcontent/ uploads/2015/07/iNACOL Blended-Learning-The-Evolution-of-Online-And-Face-toFace-Educationfrom-2008-2015.pdf

15. Anisimov, A. M. \& Bocharov, B. P. \& Voevodina, M. Yu. \& Kuznetsov, A. I. (2014). Sistema podgotovki prepodavateley $\mathrm{k}$ vnedreniyu distantsionnykh tekhnologiy v uchebnyi protsess [The system for preparation of lecturers to introduction of distance technologies in the education process]. Problemy teorii ta praktyky dystantsiynoi osvity v Ukraini Problems of theory and practice of distance education in Ukraine: Proceedings from the All-Ukrainian scientific and methodical conference. (pp. 10-12). Kharkiv: HNUBA [in Russian].

16. Kukharenko, V. M. \& Syrotenko, N. G. \& Young, G. S., Tverdokhlyevova, N. E. 2005). Dystantsiynyi navchalnyi protses [Distance training process]. K.: Millennium [in Ukrainian].

17. Kukharenko, V. M. (2016). Konnektyvystskyi dystantsiynyi kurs "Zmishane navchannya" [Connective distance course "Blended learning"]. Proceedings from: Chetverta mizhnarodna naukovo-praktychna konferentsia "MoodleMoot Ukraine 2016. Teorii i praktyka vykorystannya systemy upravlinnya navchannyam Moodle" - The Fourth International scientific and practical conference "MoodleMoot Ukraine 2016. Theories and practices of the use of the Moodle system for learning control" (Kyiv, KNUBA, 19-20 May 2016). Kyiv: KNUBA [in Ukrainian].

18. Kondakova, M. A. \& Latipova, E. V. (2013). Smeshanoye obucheniye: vedushchiye obrasovatelnyye tekhnologii sovremennosti [Blended learning: prominent education technologies of today]. Vestnik obrasovaniya - Bulletin of education, 05.2013, 54-64 [in Russian].

19. Deryglazov, L. V. \& Kukharenko, V. M. \& Perkhun, L. P. \& Tovmachenko, N. M. (2017). Dosvid vprovadzhennya i vykorystannya SDN "Prometey" i Moodle v Natsionalniy aкademii statystyky, obliku ta auditu [Experience of introduction and use of SDN "Prometey" and Moodle in the National Academy of Statistics, Accounting and Audit]. Proceedings from: Pyata mizhnarodna naukovo-praktychna konferentsia "MoodleMoot Ukraine 2017. Teorii i praktyka vykorystannya systemy upravlinnya navchannyam Moodle" - The Fifth International scientific and practical conference "MoodleMoot Ukraine 2017. Theories and practices of the use of the Moodle system for learning control'. (P. 13) (Kyiv, KNUBA, 26-27 May 2017). Kyiv: KNUBA [in Ukrainian]. 
Л. В. ДЕРИГЛАЗОВ,

кандидат фізико-математичних наук, професор, завідувач відділення заочного та дистанційного навчання,

Національна академія статистики, обліку та аудиту

B. М. КУХАРЕНКО,

кандидат технічних наук, професор,

науковий керівник проблемной лабораторіӥ дистанційного навчання, Національний технічний університет "Харківський політехнічний інститут"

Л. П. ПЕРХУН,

кандидат педагогічних наук, дочент, завідувач сектору дистанчійного навчання, Національна академія статистики, обліку та аудиту H. M. ТОВМА ЧЕНКО, кандидат технічних наук, дочент,

кафедра статистики, Національна академія статистики, обліку та аудиту

\section{Моделі дистанційного навчання в Національній академії статистики, обліку та аудиту}

Вирімення проблем освітньой системи в Украйні потребує адекватної структури й організаиії з переходом на приниип освіти протягом усього жсиття. Найкращим варіантом для цъвого є система дистанційного навчання (СДН). В статті проаналізовано і узагальнено досвід впроваджени СДН "Прометей" і Moоdle ma основні напрями розвитку дистанційиного навчання в Національной академї̈ статистики, обліку і аудиту (НАСОА). Акцентовано увагу на необхідності підвищення кваліфікації викладачів з використанням відкритих дистаниійних курсів та поступової підготовки стуудента до навчального процесу у нових умовах. Розроблено структуру дистаниійних курсів для різних форм навчання (очна, заочна, змімана). Представлено аналіз моделей форм навчання і динамічний варіант впровадження в НАСОА моделей "зміманого навчання" з використанням СДН "Прометей" і Moоdle. Досвід НАСОА показує, що змімана форма дистанційного навчання на базі платформи Моодlе є найбільи адекватною вимогам розвитку Украйни в рамках свропейськой освіти.

Ключові слова: дистанційне навчання, система дистанційного навчання, змімане навчання, освіта впродовж усього життя, інформсиійні технологій, дистаниійний курс навчання, "Прометей", Moodle. 
Л. В. ДЕРИГЛАЗОВ,

кандидат физико-математических наук, профессор, заведуюиции отделением заочного и дистанционного обучения,

Национальная академия статистики, учета и аудита

B. H. КУХАРЕНКО,

кандидат технических наук, профессор,

научный руководитель проблемной лаборатории дистанциионного обучения,

Национальный технический университет "Харьковский политехнический инcmumym"

Л. П. ПЕРХУН,

кандидат педагогических наук, дочент, заведующая сектором дистанционного обучения, Национальная академия статистики, учета и аудита Н. Н. TOBMA ЧЕНКO, кандидат технических наук, дочент, кафедра статистики,

Национальная академия статистики, учета и аудита

\section{Модели дистанционного обучения в Национальной академии статистики, учета и аудита}

Решение проблем системы образования в Украине требует адекватной структуры ее организации с переходом на принцип образования на протяжении всей жсизни. Наилучиим вариантом для этого является система дистанционного обучения (СДО). В статье проанализирован и обобщен опыт внедрения СДО «Прометей» и Moоdle, а также основные направления развития дистанционного обучения в Национальной академии статистики, учета и аудита (НАСУА). Акцентировано внимание на необходимости повынения квалификации преподавателей с использованием открытых дистаниионных курсов и постепенной подготовки студента к учебному прочессу в новых условиях. Разработана структура дистанционных курсов для разных форм обучения (очнал, заочнал, смешанная). Представлен анализ моделей форм обучения и динамический вариант внедрения в НАСУА моделей «смечанного обучения» с использованием СДО «Прометей» и Moоdle. Oпыт НАСУА показывает, что смешанная форма дистанционного обучения на базе платформы Моодlе является наиболее адекватной требованиям развития Украины в рамках европейского образования.

Ключевье слова: дистанционное обучение, система дистанционного обучения, смешанное обучение, образование на протяжении всей жизни, информационные технологии, дистанционный курс обучения, "Прометей", Mооdle.

Bibliographic description for quoting:

Deryhlazov L. V., Kukharenko V. M., Perkhun L. P., Tovmachenko N. M. (2017). The Models of Distance Forms of Learning in National Academy of Statistics, Accounting and Audit. Scientific Bulletin of National Academy of Statistics, Accounting and AuditNaukovyi visnyk Natsionalnoi akademii statystyky, obliku ta audytu, 3, P. 79-90 [in English]. 